\title{
PEMODELAN DAN PENGEMBANGAN SISTEM PENDETEKSIAN PENYAKIT INFEKSI TROPIS BERBASIS ONTOLOGI
}

\author{
Lalu Mutawalli \\ Sistem Informasi, STMIK Lombok \\ Jln. Basuki Rahmat No.105 Praya Lombok Tengah 83511 \\ lalualimikom@gmail.com
}

\begin{abstract}
Infection disease have been national or international problem. The prevalence rate of meaning is high for death. Infection disease difficulties to controlling. The occurrence of inequality ratio medical professionals is one of the things that became lack of control of infection disease. Information technology is needed to support the achievement of control, it became the base for building a modeling system that can detect the presence of infection disease, especially infectious disease with tropical infection categories. Ontology as a concept in building a system with using jaccard similarity method for calculation of the case. The result a system accuracy in this study, typhoid fever disease as much as 88\%, dengue fever as much as 96\% and malaria disease as much as 77\%. System can be able to use by paramedic as reference the beginning for anamneses also patients can be able to use as an early warning to determine the condition health.
\end{abstract}

Keywords : System Modeling, Detection, Infectious Diseases

\begin{abstract}
Abstrak
Penyakit menular selalu menjadi permaslahan nasional maupun internasional, tingkat prevalensi penyakit menulas tergolong cukup tinggi menyebabkan kematian. Sulitnya pengendalian penyakit menular karena berbagai hal termasuk kurangnya sumberdaya manusia. Terjadinya ketimpangan rasio professional medis merupakan salah satu hal yang menjadi dasar tidak tercapainya pengendalian terhadap penyakit menular. Sentuhan teknologi informasi dibutuhkan untuk mendukung tercapainya pengendalian, hal tersebut menjadi dasar untuk membangun suatu pemodelan sistem yang dapat mendeteksi keberadaan penyakit menular, khususnya penyakit menular dengan kategori infeksi tropis. Ontologi sebagai konsep dalam membangun sistem dengan metode perhitungan menggunakan jaccard similarity. Hasil akurasi sistem pada penelitian ini, penyakit demam tifoid sebanyak 88\%, penyakit demam berdarah sebanyak $96 \%$ dan penyakit malaria sebanyak $77 \%$ sehingga sistem dapat digunakan oleh paramedic sebagai refrensi pengethaun pada saat melakukan anamneses awal. Pasien dapat menggunakan juga sebagai early warning untuk mengetahui kondisi kesehatannya.
\end{abstract}

Kata kunci : Pemodelan Sistem, Deteksi, Penyakit Menular

\section{Pendahuluan}

Penyakit menular merupakan salah satu permsalahan dalam bidang kesehatan nasional di Indonesia Bahkan di dunia. Menurut data riset kesehatan dasar, penyakit menular memiliki prevalensi cukup tinggi menyebabkan kematian (Soedarto, 2009). Permasalahan penyakit menular menjadi perhatian dari berbagai aspek termasuk pemerintah Indonesia didalam Rencana Strategis Kementrian Kesehatan. Pada Keputusan Mentri Kesehatan Republik Indonesia NOMOR HK.02.02/MENKES/52/2015 bagian penyakit menular, menyatakan penyakit menular belum sepenuhnya mengendalikan penyakit menular khusnya Tubercolosis, HIV/AIDS, Malaria, Demam Berdarah, dan Demam Tifoid (Moeloek, 2015).

Berbagaihal hal yang menyebabkan penyakit menular sulit teratasi, mulai dari masalah lingkungan, life style hingga meratanya sumber daya. Kurangya tenaga professional medis (dokter) juga memiliki pengaruh terhadap penyelesaian masalah kesehatan dalam hal ini penyakit menular. Menurut data world health organization (WHO) rasio jumlah dokter 
terhadap penduduk Indonesia 243.6 juta jiwa adalah 1 dokter untuk 2,538 jiwa rasio ini lebih tinggi dari rasio dokter menurut WHO 1 dokter 2.500 jiwa (Mboi, 2014)

Terjadinya ketimpangan rasio professional medis merupakan salah satu hal yang menjadi dasar tidak tercapainya pencapaian kesehatan nasional khusnya pada kasus pengendalian penyakit menular. Keberadaan professional medis cenderung tersentral didaeah perkotaan sementara didaerah-daerah populasinya sangat minim dan sulit diakses. Dengan problem tersebut dibutuhkan sentuhan teknologi informasi untuk pendeteksian dini gejala-gejala yang muncul yang diakibatkan oleh penyakit menular, khusnya demam berdarah, demam tifoid, dan malaria.

\section{Tinjuan Pustaka}

Pada penelitian sebelumnya shofia, dkk (2017), merancang sistem pakar untuk mendiagnosis penyakit DBD, Malaria dan Tifoid penelitian tersebut bertujuan untuk mengetahui seseorang terkena penyakit jenis demam apa yang diketahui melalui gejala-gejala yang dialami oleh orang tersebut penelitian tersebut dilakukan dengan pendekatan metode K-Nearst Neighbor dan certainty factor. Berutu dan Jatmiko (2017), mengembangkan basis pengetahuan untuk merepresetasikan pengetahuan diagosa penyakit demam berdarah.

Putra, (2012), dalam penelitianya mengukur ketidak pastian terhadap penyakit infeksi tropik yang memiliki gejala-gejala yang hampir mirip sehingga sulit untuk meneggakan jenis penyakit apa yang diderita seseorang, sitem pakar untuk mendiagnosa penyakit infeksi tropik dengan menggunakan metode fuzzy sugeno sebagai metode dalam meneggakan keanggotaan suatu gejala terhadap jenis penyaki yang paling cocok dengan nilai keanggotaanya dan certanty factor digunakan sebagai perangkingan terhadap nilai yang timbul dari gejala-gejala yang timbul.

Njafa, dkk (2018), dalam penelitianya membangun QAMDiagnos model quantum asosiatif memory (QAM) yang dapat menjadi alat yang bermanfaat untuk staff medis tanpa pengalaman atau fasilitas laboratorium, untuk diagnosis empat penyakit tropis malaria, demam tifoid, hepatitis, dan demam berdarah, metode yang digunakan quantum linier algoritm retriving.

Pada penelitian sebelumnya tidak terdapat kombinasi pemodelan ontologi sebagai konsep dalam membangun sistem pendeteksian (diagnosis) penyakit infeksi tropik. Ontologi sebagai konsep dalam membangun sistem cerdas telah banyak digunakan, Simanjuntak, dkk
(2015), ontologi digunakan dalam membangun pengetahuan penyakit saraf. Chi, dkk (2015) membangun sistem rekomendasi kelompok makan kaya nutrisi dan serat. Sappagh, dkk (2017) membangun sistem untuk mendiagnosa dan mengobati penyakit diabetes militus dengan menggunakan kosep ontologi sebagai model pengetahuan sistem. Chen, dkk (2012) menggunakan ontologi untuk membangun sistem rekomendasi obat anti diabetes.

Dari beberapa paparab penelitian diatas bahwa ontologi telah sukses digunakan sebagai konsep pemodelan pengatahuan sistem medis oleh karena penelitian ini akan menggunkan ontologi sebagai konsep dalam membangun pengetahuan sistem deteksi penyakit infeksi tropik kemudian menggunakan metode jaccard similarity untuk menghitung kemiripan gejalagejala yang muncul dengan kondisi yang timbul.

\section{Metodologi Penelitian}

\subsection{Metode Pengumpulan Data}

\section{Wawancara}

Melakukan wawancara dengan dokter spesialis penyakit dalam di Rumah Sakit Umum Harapan Anda Kota Tegal.

\section{Sumber Data}

Data yang digunkan adalah data pasien yang telah dirawat di Rumah Sakit Umum Islam Harapan Anda Kota Tegal.

\section{Studi Pustaka}

Memperlajari buku panduan yang direkomendasikan oleh dokter spesialis penyakit dalam, yaitu buku kapita selekta kedokteran dan nanda pedoman keperawatan yang merupakan literatur yang digunkan sebagai tuntunan perawatan.

\subsection{Metode Perhitungan}

Metode yang digunakan untuk perhitungan kemiripan adalah jaccard similarity dengan asumsi kasus yang dimasukkan seberapa tepat kemiripanya dengan pengetahuan yang ada pada sistem Tan, dkk (2005).

$I(X, Y)=\frac{\sum_{i=1}^{p} x_{i} y_{i}}{\sum_{j=1}^{p} x_{i}^{2}+\sum_{j=1}^{p} y_{i}^{2}-\sum_{i=1}^{p} x_{i} y_{i}}$

Dimana x merupakan nilai dari pengetahuan dan y nilai dari data uji. 


\subsection{Pemodelan Pengetahuan}

Pengetahuan dimodelkan menggunakan konsep ontology kemudian dibentuk rule yang menghubungkan antara suatu peristiwa yang muncul dikarenakan suatu gejala yang timbul pada pasien. Fudholli, dkk (2015) merekomendasikan Metode semantic web rule language (SWRL) digunakan untuk membangun rule model terhadap ontologi.

\begin{tabular}{|c|c|}
\hline $\begin{array}{l}\text { Rule1_// } \\
\text { _Pasien }\end{array}$ & 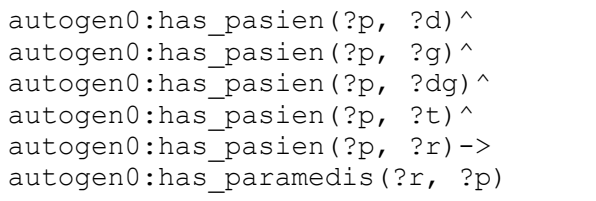 \\
\hline $\begin{array}{l}\text { Rule2_// } \\
\text { penyaki }\end{array}$ & $\begin{array}{l}\text { autogen } 0 \text { :has_penyakit }(? d, ? \text {, })^{\wedge} \\
\text { autogen } 0: \text { has_penyakit }(? d, ? \text { dg)^ }\end{array}$ \\
\hline$t$ & $\begin{array}{l}\text { autogen } 0 \text { :has_penyakit }(\text { ?d, ?t)^ } \\
\text { autogen } 0 \text { :has_pasien (?p, ?d) }-> \\
\text { autogen } 0: \text { has_pasien (?p, ?d) }\end{array}$ \\
\hline $\begin{array}{l}\text { Rule3_// } \\
\text { Tata_La } \\
\text { ksana }\end{array}$ & $\begin{array}{l}\text { autogen } 0: \text { has_tata_laksana }(? t, \text { ?d)^ } \\
\text { autogen } 0: \text { has_tata_laksana (?t, ?p) }{ }^{->} \\
\text {autogen } 0: \text { has_pasien }(? p, \text { ? })\end{array}$ \\
\hline $\begin{array}{l}\text { Rule4_// } \\
\text { Diagnos } \\
\text { is }\end{array}$ & $\begin{array}{l}\text { autogen } 0 \text { :has_diagnosis }(? d g, ? g)^{\wedge} \\
\text { autogen } 0 \text { : has_diagnosis (?dg, ?p) }-> \\
\text { autogen0:has_diagnosis (?dg, ?p) }\end{array}$ \\
\hline
\end{tabular}

Gamabar 3.1 Rule SWRL Ontologi infeksi tripoik

\section{Hasil dan Pembahasan}

\subsection{Alur Akusisi Pengetahuan Sistem}

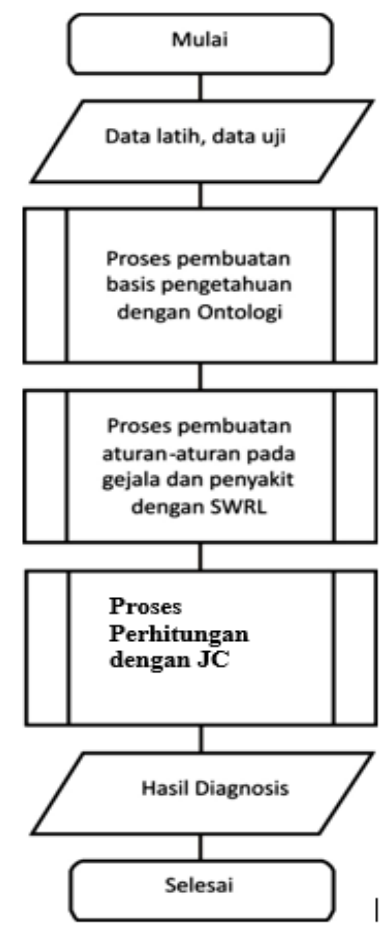

Gambar 4.1 Alur Akusisi Pengetahuan
Keterangan Gambar:

1. Data yang pengetahuan pakar, studi liteatur, dan sebgian data pasien dimasukkan sebagai basis pengetahuan.

2. Ontologi mengakomodasi kumpulan data pengetahuan lalu disusun sesuai dengan kelas dan properti masing-masing.

3. Membangun aturan dengan SWRL aturan tersebut berupa gejala-gejala. Sebagai ilustrasi jika $\mathrm{x}, \mathrm{y}, \mathrm{z}$ (gejala) maka kondisi $\mathrm{n}$ (penyakit).

4. Basis pengetahuan yang telah dibagun diuji dengan data pasien, proses perhitungan dilakukan dengan menggunakan jaccard similarity. Dengan asusmsi apabila data uji memiliki kemiripan dengan data yang ada didalam basis pengetahuan maka kondisi yang timbul akibat suatu gejala akan ditetapkan sebagai suatu penyakit Demam Beradarh, Demam Tifoid atau Malaria.

\subsection{Implementasi Basis Pengetahuan}

Basis pengetahuan divisualisasi dengan menggunakan tools protégé versi 4.3.0 dengan asusmsi sesorang memiliki gejala-gejala timbul akibat virus dan menimbulkan jenis penyakit.

\section{Kelas}

Berdasarkan tahapan dan penanganan kasus demam berdarah, demam tifoid, malaria.

\section{owl:Thing \\ -... Tata_Laksana \\ Pencatatan \\ Diagnosis \\ Gejala \\ Pemeriksaan_Penunjang \\ penyakit \\ person \\ Paramedis \\ Pasien}

Gambar 4.2 Kelas ontologi infeksi tropik

Keterangan gambar:

1. Kelas tata laksana adalah kelas yang berfungsi untuk menakomodasi aturan yang berfungsi dalam tata laksana perawatan penyakit.

2. Kelas pencatatan berfungsi untuk menyimpan hasil dari proses rekam medis pasien.

3. Kelas diagnosa berfungsi untuk menyimpan aturan-aturan diagosa suatu penyakit.

4. Kelas gejala berfungsi untuk menyimpan gejalagejala yang muncul terhadap penyakit.

5. Kelas person terdiri menjadi dua sub kelas, kelas paramedis adalah merupakan seorang atau sekumpulan ahli dalam bidang kedokteran, seperti dokter dan perawat atau profesi lainya 
yang memiliki otoritas dalam memberikan pelayanan kesehatan. Sub kelas kedua adalah kelas pasien merupakan individu yang menderita suatu penyakit.

2. Objek properti dan data properti

Objek properti adalah merupakan objek yang berfunsi untuk menyimpan suatu tindakan yang dilakukan terhadap penyakit. Data properti berfungsi untuk menyimpan semua data yang merupakan instance dari ontologi penyakit infeksi tropis.

\begin{tabular}{cc}
\hline owl:topobjectProperty & owl:topDataProperty \\
has_diagnosis & alamat \\
has_tata_laksana & detail_rekam \\
has_tugas & tinggi_badan \\
has_informasi_rekam & berat_badan \\
has_laboratorium & usia \\
has_gejala & nama \\
has_penyakit & ho_rekam \\
has_member & has_paramedis
\end{tabular}

Gambar 4.3 Objek dan data properti

3. Impementasi ontologi penyakit

Pada bagian ini memvisualisasi bagaimana proses reasoning terhadap proses terjadinya penyakit dan penangananya.

\subsection{Rancangan Interface Sistem}

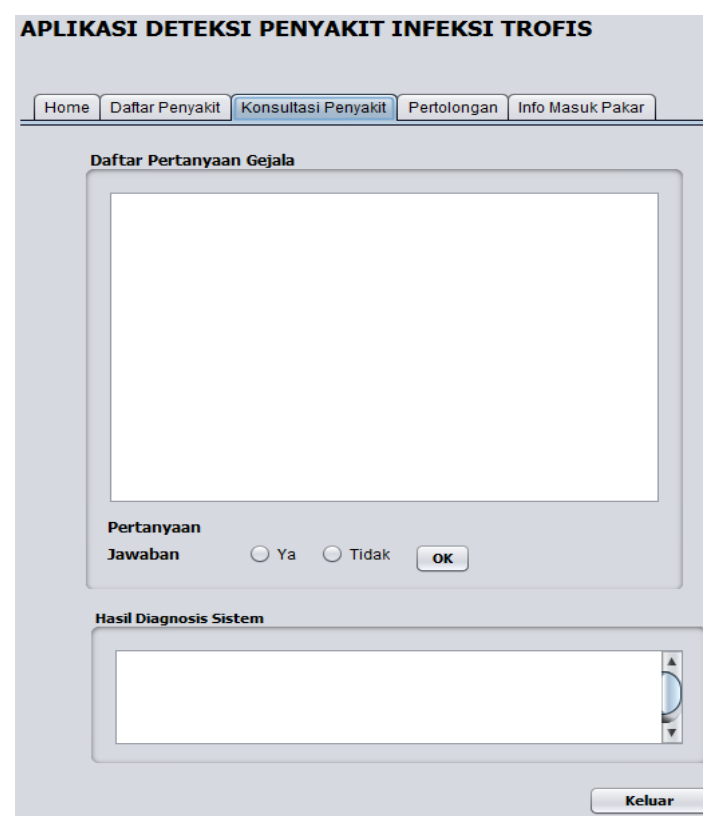

Gambar 4.5 Rancangan Interface Deteksi

Pada rancangan interface tampak seperti pada gambar 4.5 terdapat lima menu utama. Menu home adalah menu yang pertama kali
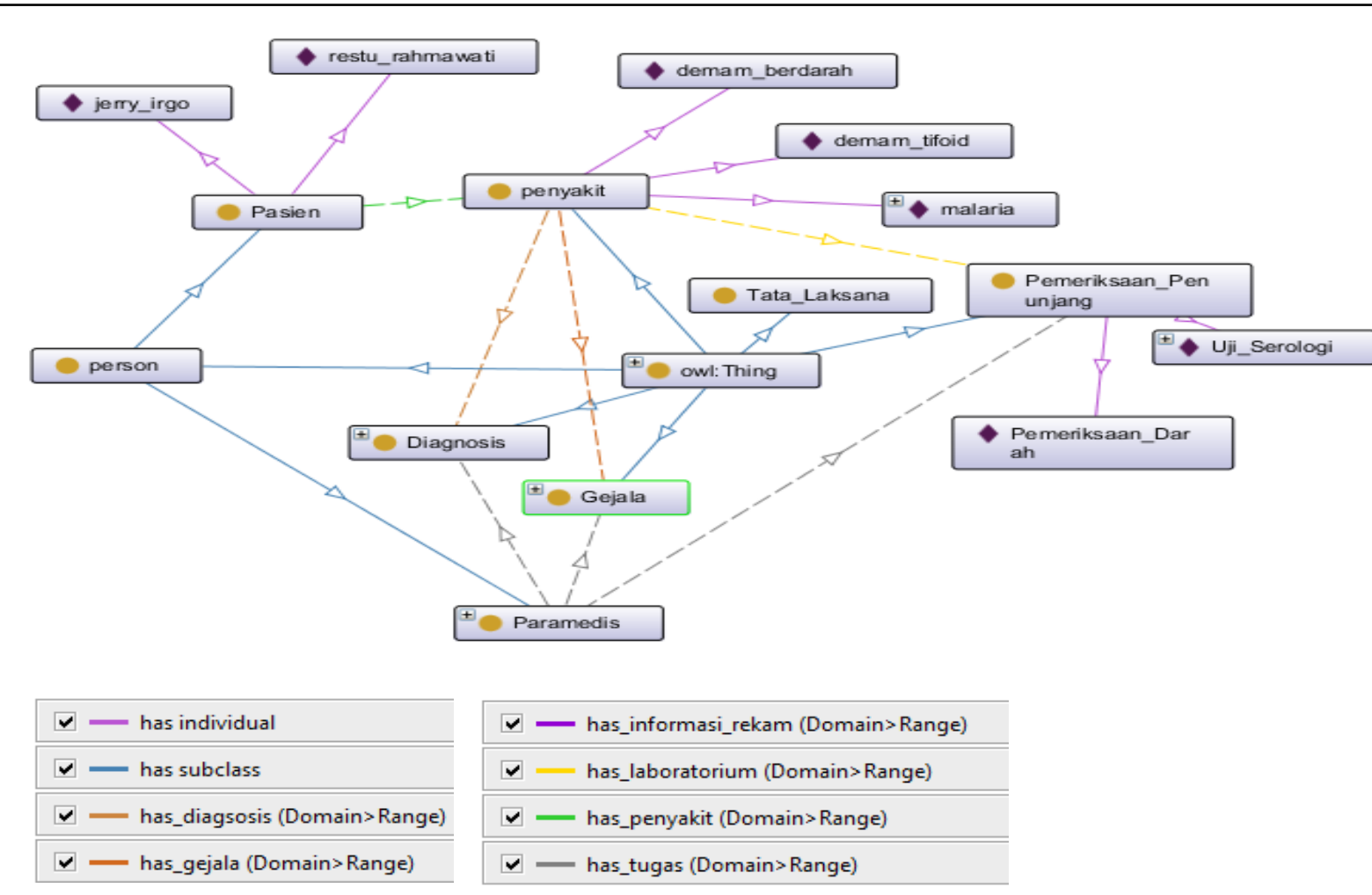

Gambar 4.4 Ontologi penyakit infeksi trofik 
muncul saat aplikasi dibuka. Menu Daftar penyakit berisikan jenis-jenis penyakit yang ada pada sistem. Konsultasi menu ini adalah menu yang digunakan untuk memproses perhitungan dari gejala-gejala yang timbul dengan penyakit yang diderita. Menu pertolongan berisi tentang cara menggunakan program. Menu masuk pakar adalah merupakan menu master untuk menginputkan pengetahuan-pengetahuan yang diproses oleh sistem.

Data yang dibutukan pada penelitian ini adalah data pasien dengan jenis penyakit Demem Berdarah, Demam Tifoid, dan Malaria. Data tersebut dijadikan sebagai datalatih.

\subsection{Penujian dan Analisis}

Pengujian dilakukan untuk mengetahuai apakah sistem akurat dalam mendeteksi penyakit.

Tabel 4.1 Hasil Uji Akurasi

\begin{tabular}{|l|l|c|c|}
\hline No & \multicolumn{1}{|c|}{$\begin{array}{c}\text { Nama } \\
\text { Penyakit }\end{array}$} & $\begin{array}{c}\text { Similar } \\
\mathbf{\%}\end{array}$ & Hasil \\
\hline 1. & $\begin{array}{l}\text { Demam } \\
\text { Tifoid }\end{array}$ & 0.88 & Akurat \\
\hline 2. & $\begin{array}{l}\text { Demam } \\
\text { Berdarah }\end{array}$ & 0.96 & Akurat \\
\hline 3. & Malaria & 0.77 & Akurat \\
\hline
\end{tabular}

Akurasi yang dihasilkan oleh sistem untuk mendeteksi penyakit demam tifoid sebesar $88 \%$, pada penyakit demam berdarah sebanyak 96\%, dan penyakit malaria 77\%. Dapat juga dilihat pada Gambar 4.5 visualisasi dalam bentuk grafik dari pada nilai akurasi.

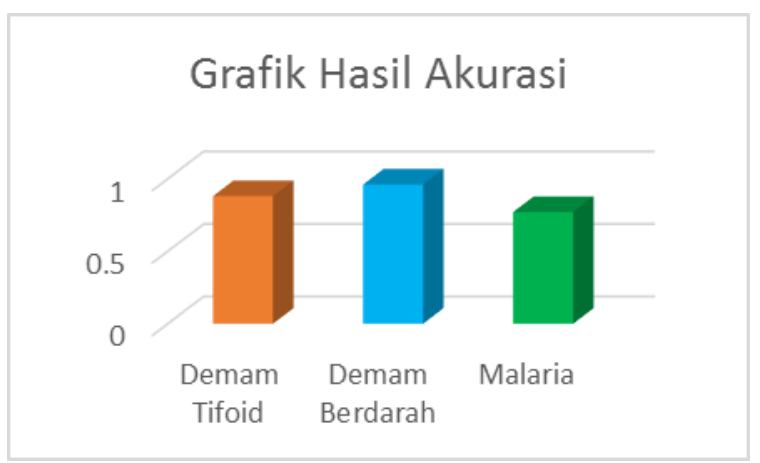

Gambar 4.6 Visulasisasi Hasil Akurasi

\section{Kesimpulan dan saran}

1. Kesimpulan

Berdasarkan hasil penelitian sistem deteksi dini penyakit infeksi tropic dengan menggunakan metode ontologi dan jaccard similarity, pemodelan pengetahuan menggunakan ontologi dan metode perhitungan menggunakan jaccard similarity. Hasil pengujian menggunakan jaccard similarity didapatkan nilai akurasi pada setiap penyakit, pada penyakit demam tifoid sebesar 88\%. Pada penyakit demam berdarah sebesar 96\% dan Malaria 77\%. Akrasi tertinggi terdapat pada pendeteksian penyakit demam berdarah.

\section{Saran}

Jika melihat dari hasil nilai akurasi bahwa hasil tidak selalu konsisten, dimana pada setiap nilai yang dihasilkan perbedaanya cukup jauh, hal tersebut dikarenakan data yang digunakan sebagai basis pengetahuan adalah pada pasien rawat inap, diperlukan data pasien rawat jalan sebagai data komparasi untuk mengetahui sifatsifat penyakit lebih rinci. Jenis penyakit infeksi tropis yang lainya juga diharapkan dalam penelitian selanjutnya agar dapat mengetahui sistem yang dirancang dapat mengakomodasi banyak jenis penyakit infeksi tropis.

\section{Daftar Pustaka:}

Berutu, S. S., Jatmika, Ontology Pada Diagnosa Penyakit Demam Berdarah. Prosidig Seminar Nasional Sisfotek Sistem Informasi dan Teknologi Informasi.

Chi, Y. L, Chen, T. Y, Tsai, W. T, 2015, A Chronic Dietary Consultation System Using OWLBased Ontologies and Semantic Rule. Journal of Biomedical Informatics, Department of Information Management Chung Yuan University. Chung Li City Taiwan.

Chen, R, Huang, Y. H, Bau, C. T, Chen, S. M, 2012, A Recommendation System Based on Domain Ontology and SWRL for Anti Diabetic Drugs Selection. Journal Expert System With Application.

Fudholli, D. H, Wenny, R, Pardede, Eric, 2015, A Data Driven Dynamic Ontology. Journal of Information Science.

Maneerat, N, Varakulsiripunth, R, Fudholli, D. H, 2013, Ontology Based Nutrition Planning Assistance System for Health Control, ASEAN Engineering Jaournal.

Moeleok, N. P, 2015, Rencana Strategis Kementrian Kesehatan, Kemenkes RI, Jakarta.

Mboi, N. (2014, Maret 24). Peran Jumlah dan Mutu Tenaga Kesehatan. Dipetik http://www.depkes.go.id/article/print/201 43250004/peran-jumlah-dan-mutu-tenagakesehatan-dukung-percepatan-mdgs-danimplementasi-jkn.html November 18, 2017, 
dari Pusat Komunikasi Publik Sekretariat Jenderal Kementerian Kesehatan RI:.

Njafa, T, Engo, N, 2018, Quantum Associative Memory With Linier and Non Linier Algorithm for The Diagnosis of Some Tropical Disease. Journal Neura Network.

Putra, I. G, Prihatini, P. M, 2012, Fuzzy Expert System for Tropical Infection Disease by Certainty Factor, Journal Telecommunication Computing Electronic and Control.

Shopia, E., Putri, R., Arwan, Sistem Pakar Diagnosis Penyakit Demam: DBD, Malaria, dan Tifoid Menggunakan Metode K-Nearest Neighhbor-Certainty Factor. Jurnal Pengembangan Teknologi Informasi dan Ilmu Komputer.

Khairul Imtihan. "Perencanaan Strategi Sistem Informasi Pendidikan Pada Sekolah Tinggi Manajemen Informatika dan Komputer (STMIK) Lombok." Bianglala Informatika 3.2 (2015).
Rohana, and Khairul Imtihan. "Sistem Informasi Keluhan Pelanggan Pada Perusahaan Daerah Air Minum (PDAM) Kabupaten Lombok Tengah." Jurnal Manajemen Informatika dan Sistem Informasi 1.1 (2018): 24-30.

Soedarto, 2009, Penyakit Menular di Indonesia, Penerbit Sagung Seto, Yogyakarta.

Simanjuntak, C. H, Kusumawardani, S. S, Permanasari, A. E, 2015, Perancangan Ontologi Domain Pengetahuan Saraf Berbasis SWRL Dengan Metode Methontology. Seminar Nasional Teknologi Informasi dan Komunikasi Terapan.

Sappagh, S, Elmogy, M, 2017. A Fuzzy Ontology Modeling For Case Base Knowledge in Diabetes Militus Domaian. Science and Technology an International Journal.

Tan, P. N, Steinbach, M, Kumar, Vipin, 2005. Introduction to Data Mining, Pearson Education Limited, USA. 